\title{
REVIEW KLORINASI ZIRKON DIOKSIDA
}

\author{
Dwiretnani Sudjoko \\ PTAPB - bATAN Yogyakarta
}

\begin{abstract}
ABSTRAK
REVIEW KLORINASI ZIRKON DIOKSIDA. Telah dilakukan review klorinasi zirkon dioksida menggunakan proses semi catu dengan reaktor datar, reaktor tegak dan reaktor fluidisasi. Umpan yang digunakan zirkon dioksida buatan Aldrich, pasir zirkon langsung dan pasir zirkon dalam bentuk briket. Dari hasil kajian didapatkan bahwa reaktor yang terbaik adalah reaktor tegak. Diperlukan modifikasi reaktor klorinasi dan sublimator untuk mendapatkan konversi yang lebih besar. Zirkonium tetraklorid hasil proses ternyata signifikan dengan zirkonium tetraklorid buatan Aldrich. Diperlukan penelitian lebih lanjut untuk mendapatkan hasil proses yang lebih baik.
\end{abstract}

\section{ABSTRACT}

REVIEW OF CHLORINATION OF ZIRCONIUM DIOXIDE. A review of chlorination zirconium dioxide is presented.used semi batch process with vertical reactor, horizontal reactor and fluidized reactor. The feed were zircondioxide from Aldrich, direct zircon sand and briquet of zircon sand. From the study it is obtained that the best reactor is vertical reactor.It needs modification of chlorination reactor and sublimator to obtain the larger conversion. It is come to reality that zirconium tetrachloride preparation by process is significant with zirconium tetrachloride from Aldrich. It needs the sequel research to get the best result of process.

\section{PENDAHULUAN}

$I$ ndonesia adalah negara yang kaya sumber daya alam. Sebagian sumber daya alam tersebut dieksploitasi baik sebagai bahan mentah maupun diolah dengan nilai tambah yang lebih tinggi. Pemanfaatan melalui pengembangan industri memberi peningkatan nilai tambah, penyerapan tenaga kerja dan tumbuhnya sektor informal.

Klorinasi zirkonium dioksida akan menghasilkan zirkonium tetraklorida. Zirkonium tetraklorida merupakan umpan pada pembuatan logam zirkonium. Zirkonium tetraklorida juga digunakan untuk pembuatan senyawa zirkonium yang lain, misalnya dalam industri keramik, dalam solid oxide fuel cells yang menggunakan zirkonium dioksida sebagai elektrolit padat antara kedua katoda dan anoda. Sumber zikonium dioksida di Indonesia adalah pasir zirkon dalam bentuk senyawa $\mathrm{ZrO}_{2} \cdot \mathrm{SiO}_{2}$ atau dapat dinyatakan sebagai $\mathrm{ZrSiO}_{4}$ yang merupakan hasil samping pabrik timah Bangka, dari Kalimantan dalam bentuk lumpur mineral ${ }^{(3)}$. Selama ini pasir zirkon dari pulau Bangka hanya dijual tanpa diolah terlebih dahulu, sehingga nilai ekonomisnya tidak begitu tinggi. Oleh karena itu perlu dilakukan penelitian untuk dapat meningkatkan nilai ekonomis tersebut. Salah satu penelitian yang dilakukan adalah pembuatan zirkonium tetraklorida dengan proses klorinasi.

Penelitian yang dilakukan bertujuan membuat umpan untuk pembuatan logam zirkonium. Pembuatan zirkonium tetraklorida dapat ditempuh beberapa cara antara lain klorinasi pasir zirkon secara langsung, melalui zirkonium dioksida kemudian diklorinasi atau menggunakan zirkonium oksida hasil dari pabrik untuk menghasilkan zirkonium tetraklorida. Pembuatan zirkonium tetraklorida secara langsung dari pasir zirkon maupun melalui zirkonium dioksida ${ }^{(1,2)}$ dilakukan dengan klorinasi sesuai reaksi

$$
\mathrm{ZrSiO}_{4} \text { (padat) }+2 \mathrm{C} \text { (padat) }+4 \mathrm{Cl}_{2} \text { (gas) } \rightarrow \mathrm{ZrCl}_{4} \text { (gas) }+\mathrm{SiCl}_{4} \text { (gas) }+2 \mathrm{CO}_{2}
$$

Apabila digunakan umpan berupa zirkon dioksida reaksinya adalah sebagai berikut

$$
\begin{aligned}
& 1 / 2 \mathrm{ZrO}_{2}+\mathrm{C}+\mathrm{Cl}_{2} \longrightarrow 1 / 2 \mathrm{ZrCl}_{4}+\mathrm{CO} \\
& 1 / 2 \mathrm{ZrO}_{2}+\mathrm{CO}+\mathrm{Cl}_{2} \longrightarrow 1 / 2 \mathrm{Zrl}_{4}+\mathrm{CO}_{2} \\
& \mathrm{ZrO}_{2}+\mathrm{C}+\mathrm{Cl}_{2} \longrightarrow \mathrm{ZrCl}_{4}+\mathrm{CO}_{2}
\end{aligned}
$$


Reaksi 3 dominan pada suhu rendah, sedangkan reaksi 1 dominan pada suhu tinggi ${ }^{(1,2)}$. Dari ketiga reaksi tersebut reaksi 3 merupakan penjumlahan dari reaksi 1 dan 2. Reaksi klorinasi melibatkan reaksi antara 2 komponen padatan dan gas, sehingga merupakan reaksi yang sangat kompleks.

Peralatan yang digunakan pada proses klorinasi mempunyai diagram alir sebagai berikut ;

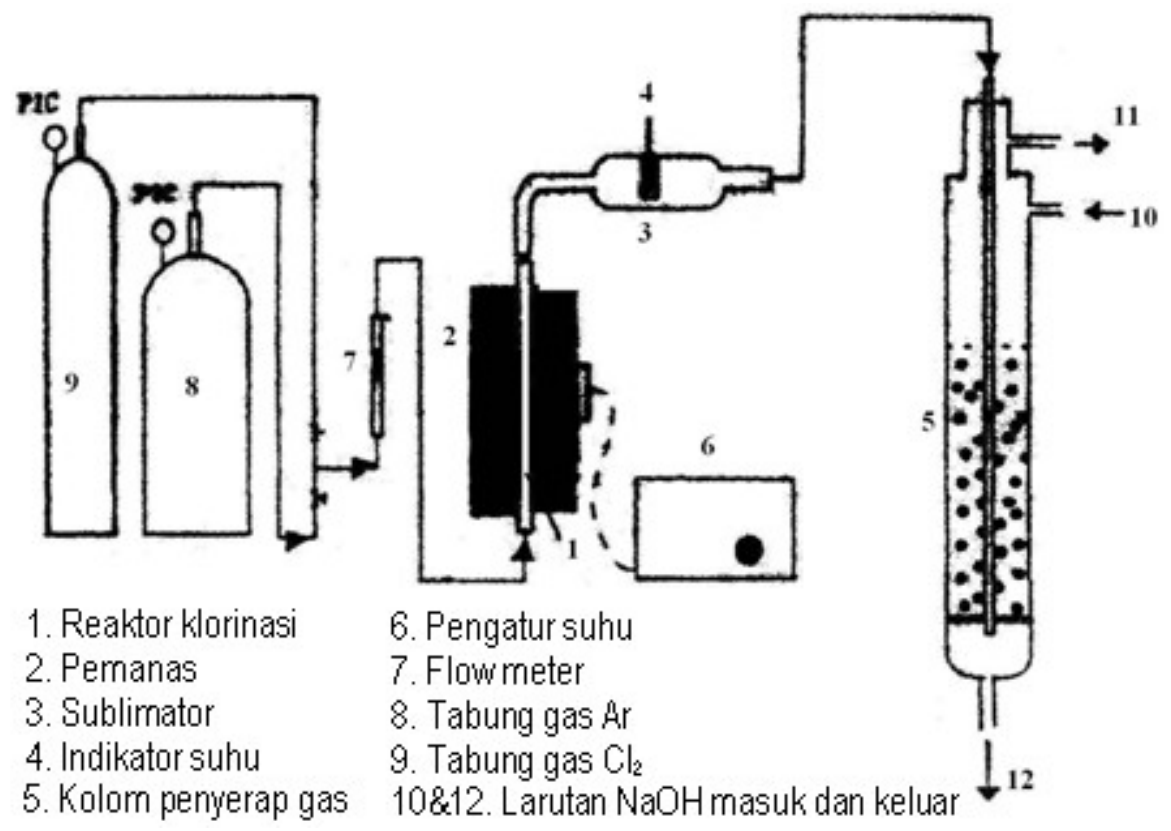

Gambar 1.Rangkaian alat klorinasi

Penelitian klorinasi menggunakan reaktor tegak telah dilakukan ${ }^{(3-7,10-19,21)}$, sedangkan penelitian menggunakan reaktor datar dilakukan oleh Sunardjo, $\mathrm{dkk}^{(7,8)}$. Proses yang digunakan adalah proses semi catu, dengan cara klorinasi langsung, campuran terdiri dari pasir zirkon ataupun zirkon dioksida dan petroleum coke, yang diletakkan dalam reaktor klorinasi, kemudian ditambah dengan gas klor. Proses ini menguapkan komponen zirkonium, hafnium, silikon, besi, aluminium dan beberapa elemen lain yang jumlahnya kecil dalam bentuk senyawa klorida. Pada sublimator terjadi sublimasi fraksinasi dan kondensasi, $\mathrm{ZrCl}_{4}$ dan $\mathrm{HfCl}_{4}$ dipisahkan dari fase gas dalam bentuk padatan, merupakan garam kotor yang juga berisi sejumlah pengotor logam lain dan produk reaksi karbon. Gas yang keluar dari sublimator mengandung sisa komponen metalik klorida, gas klor yang tidak bereaksi, gas $\mathrm{Ar}$ yang digunakan sebagai gas pembersih dan sebagian kecil komponen $\mathrm{CCl}_{4}$ yang sangat beracun. Klorinasi menggunakan gas yang sangat korosif, suhu tinggi $600-1000{ }^{\circ} \mathrm{C}$, sehingga memerlukan ketelitian, karena kebocoran gas mudah terjadi. Makin tinggi suhu, ratio penguapan zirkonium makin besar ${ }^{(15)}$, sehingga klorinasi lebih baik dilakukan pada suhu tinggi. Peralatan untuk proses fluidisasi secara skematis dapat dilihat pada Gambar 2.

Proses ini juga dikerjakan semi catu. Sejumlah umpan diletakkan dalam reaktor fluidisasi, kemudian kecepatan fluidisasi diatur dengan mengalirkan udara menggunakan blower dan gas $\mathrm{Cl}_{2}$ dialirkan bersamasama. Proses selanjutnya sama dengan klorinasi yang lain.

Hasil $\mathrm{ZrCl}_{4}$ yang diambil dari sublimator masih banyak mengandung pengotor sehingga memerlukan tahap pemurnian lebih dahulu sebelum memasuki tahap proses selanjutnya. Ada beberapa cara pemurnian yang telah dilakukan antara lain proses sublimasi-desublimasi dan distilasi fraksinasi. Pada Gambar 3 tertera rangkaian alat sublimasi-desublimasi atau disingkat alat purifikasi

Purifikasi dimulai dengan menghaluskan $\mathrm{ZrCl}_{4}$ dari sublimator, kemudian diayak sampai lolos ayakan 200 mesh, selanjutnya dimasukkan ke dalam tempat umpan. Proses sublimasi dan desublimasi dilakukan dengan dialiri gas $\mathrm{H}_{2}$, yang berfungsi sebagai reduktor dari beberapa pengotor, misalnya feri klorida yang mudah 
menguap direduksi menjadi fero klorida yang tidak mudah menguap sehingga pada proses pemurnian tertinggal sebagai residu. Sisa gas yang tidak terdesublimasi dan sisa gas $\mathrm{H}_{2}$ yang tidak bereaksi dibakar dengan api langsung menggunakan gas LPG sebelum masuk ke penyerap gas. Purifikasi dengan distilasi fraksinasi secara prinsip sama dengan cara sublimasi dan desublimasi. Perbedaannya tidak menggunakan gas $\mathrm{H}_{2}$. Rangkaian alat distilasi fraksinasi dapat dilihat dalam Gambar 4.

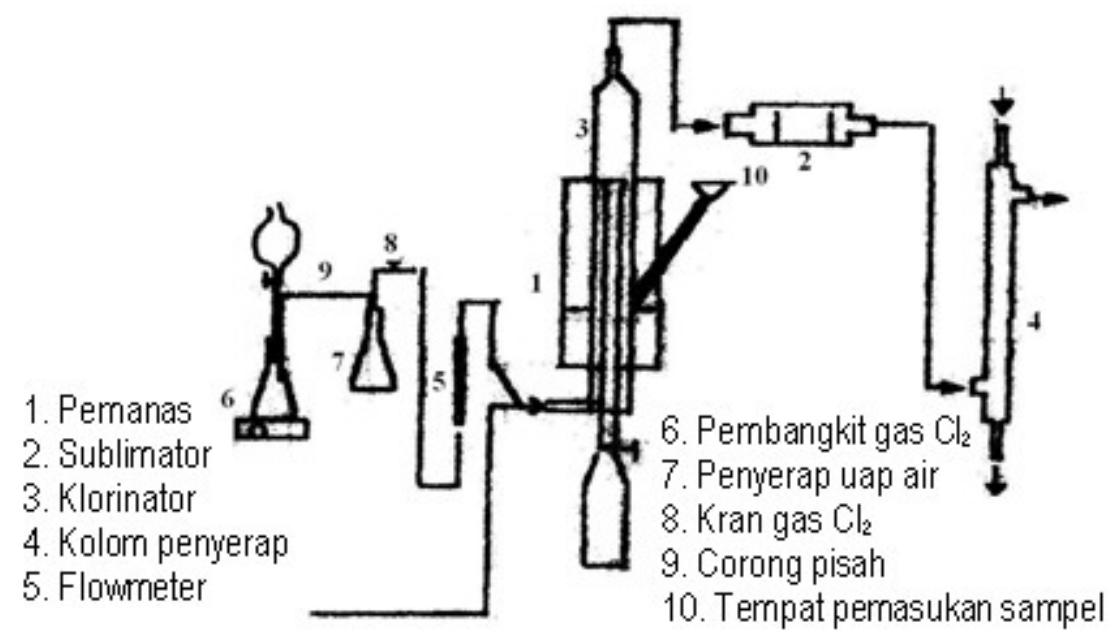

Gambar 2. Rangkaian alat klorinasi dengan fluidisasi



7. Pemanas

8. Pengatur suhu

9. Trap gas

10. Tabung gas $L P G$

11. Pembakar gas $\mathrm{H}_{2}$

12. Ke penyerap gas

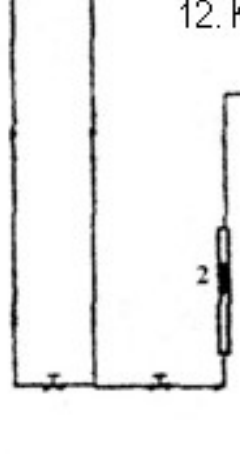

3. Desublimator \&sublimator

4. Manometer

5. Indikator suhu

6. Tempat umpan

Gambar 3. Rangkaian alat purifikasi

Cara kerja alat distilasi fraksinasi sama dengan alat purifikasi dengan sistem vakum, tanpa menggunakan $\mathrm{H}_{2}$, sehingga rangkaian alat lebih sederhana. Prinsip kerja juga dengan sublimasi dan desublimasi, tetapi tanpa gas $\mathrm{H}_{2}$, sehingga pemisahan dengan pengotor berdasarkan perbedaan suhu desublimasi ${ }^{(20)}$. Hasil-hasil penelitian yang diperoleh berupa data optimasi, kinetika dan efisiensi.

Beberapa hasil yang telah diperoleh pada penelitian klorinasi antara lain, pada proses klorinasi reaksi yang terjadi antara zirkonium oksida, karbon dan $\mathrm{Cl}_{2}$ mengikuti reaksi orde 1 terhadap $\mathrm{ZrO}_{2}$, proses yang mengontrol 
adalah reaksi kimia dan difusi secara bersama-sama. Mekanisme reaksi pada suhu $600-700^{\circ} \mathrm{C}$ adalah reaksi paralel dengan tenaga pengaktif sebesar $31904,94 \mathrm{kal} / \mathrm{mol}$, sedangkan pada suhu di atas $700^{\circ} \mathrm{C}$, terjadi reaksi seri atau tunggal dengan tenaga pengaktif $-27989,57 \mathrm{kal} / \mathrm{mol}$. Anggapan reaksi berlangsung secara grain model tidak terbukti, sedangkan anggapan reaksi antara gas dan padatan berlangsung sesuai shrinking core model terbukti ${ }^{(3,4)}$.

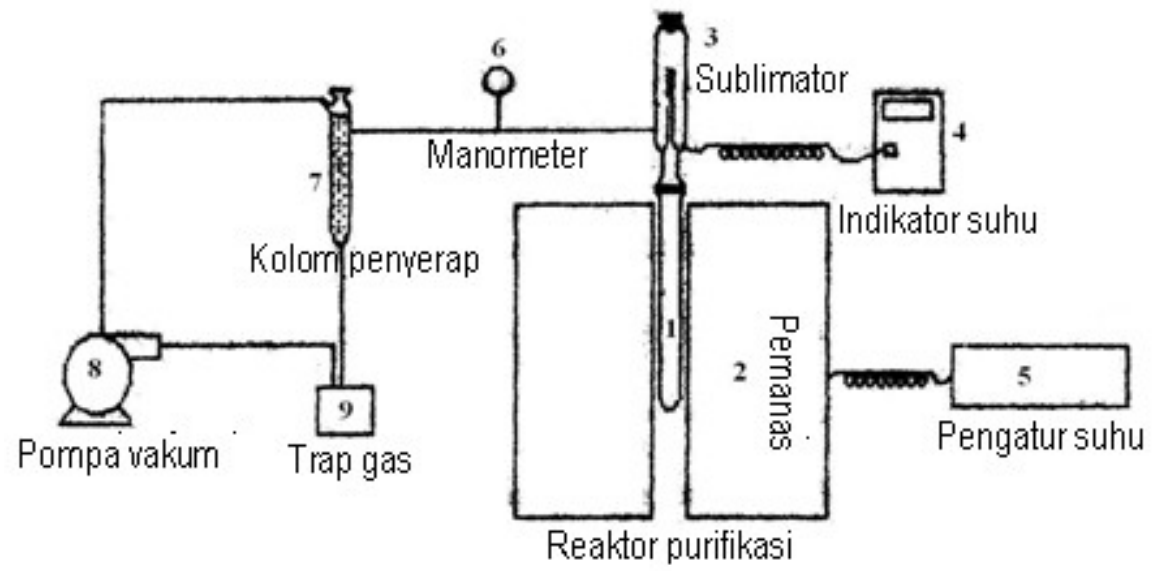

Gambar 4. Rangkaian alat distilasi fraksinasi

Hubungan antara $\mathrm{k}$, konstante kecepatan reaksi dan $\mathrm{T}$, suhu ${ }^{0} \mathrm{~K}{ }^{(5)}$

$$
\text { In } k=-16056,84 \cdot(1 / T)+11,34
$$

Pada proses yang dilakukan secara semi catu menggunakan reaktor tegak, konversi yang diperoleh kecil, menggunakan umpan $\mathrm{ZrO}_{2}$ dari Aldrich konversi $15,3 \%$, sedangkan menggunakan pasir zirkon dalam bentuk briket $^{(6,7)}$, konversi $15,3 \%$ (variabel kecepatan gas klor dan ukuran briket), konversi 35,63\% (variabel distributor gas dan ukuran briket) dan konversi $18,6 \%^{(10,11,12)}$ (variabel kecepatan gas klor dan tinggi bed, komposisi bahan briket dan tekanan pembriketan). Untuk penelitian klorinasi dengan reaktor datar didapat konversi $7,31 \%{ }^{(8)}$ (variabel suhu dan waktu) dan konversi $21,52 \%{ }^{(9)}$ (variabel jumlah oksigen dan ukuran butir karbon).

Penelitian menggunakan umpan pasir zirkon secara langsung, memberikan efisiensi klorinasi $27 \%{ }^{(13)}$ (variasi waktu, perbandingan pereaksi dan ukuran butiran pasir) sedangkan kadar Zr optimum $50,42 \%{ }^{(14)}$.

Penelitian klorinasi dengan proses fluidisasi mendapatkan konversi optimum $9,2 \%{ }^{(16)}$ (variasi suhu dan waktu fluidisasi), konversi $6,92 \%{ }^{(17)}$ (variasi kecepatan fluidisasi dan kecepatan gas $\mathrm{Cl}_{2}$ ) dan konversi $12,17 \%$ (variasi ukuran butir pasir dan ukuran butir kokas). Adapun efisiensi sublimator optimum pada alat klorinasi adalah $26,945^{(21)}$.

Pada proses purifikasi efisiensi reaktor pemurnian maksimum $65,44 \%{ }^{(5)}$, koefisien perpindahan massa pada desublimasi $\mathrm{ZrCl}_{4}$ berubah secara linier dengan perubahan kecepatan gas ${ }^{(9)}$, kemampuan sublimator dalam desublimasi $\mathrm{ZrCl}_{4}$ adalah sebesar $60,19 \%$. Makin tinggi suhu purifikasi hasil yang diperoleh makin murni, karena pengotor belum sempat menyublim sudah keluar sublimator. Pemurnian menggunakan alat distilasi fraksinasi akan menaikkan kandungan $\mathrm{Zr}$ dari 5,65\% menjadi 21,26\%, pengotor $\mathrm{Cr}$ sedikit naik dari 0,12\% menjadi 0,16\% tetapi pengotor Fe menjadi tidak terdeteksi ${ }^{(20)}$

Hasil $\mathrm{ZrCl}_{4}$ yang diperoleh dari proses klorinasi telah dianalisis menggunakan FTIR dan dibandingkan dengan $\mathrm{ZrCl}_{4}$ buatan Aldrich, hasilnya dapat dilihat dalam Gambar 5 dan Gambar $6^{(13)}$.

Untuk interpretasi hasil ini digunakan cara dari Conley ${ }^{(22)}$. Spektra hasil yang terjadi sangat berbeda dengan hasil untuk bahan organik, karena spektra hasil memiliki lebar pita serapan yang lebih sempit dan tiap anion memiliki pita serapan yang khas. Dalam spektra bahan anorganik, ciri khas pita serapan ditentukan oleh anion 
yang ada, sedangkan kation akan menggeser pita serapan ke arah frekuensi yang lebih rendah (panjang gelombang yang lebih besar). Spektra $\mathrm{ZrCl}_{4}$ buatan Aldrich memperlihatkan dua pita serapan yang menjadi ciri khas ion Cl. Daerah pita serapan yang kuat ada di daerah antara $2600-3163 \mathrm{~cm}^{-1}$ dan daerah pita serapan di daerah 1560-1624 $\mathrm{cm}^{-1}$. Untuk spektra hasil proses daerah pita serapan yang kuat ada di sekitar 2700-3386 dan $1559-1624 \mathrm{~cm}^{-1}$. Selain itu timbul satu pita serapan lagi yaitu di daerah antara 950-1089,7 cm${ }^{-1}$. Dilihat dari dua puncak yang pertama, kedua spektra ini signifikan, sedangkan untuk spektra ketiga ada dua kemungkinan penyebabnya, yaitu adanya pengotor atau fenomena hidrasi ${ }^{(3)}$.

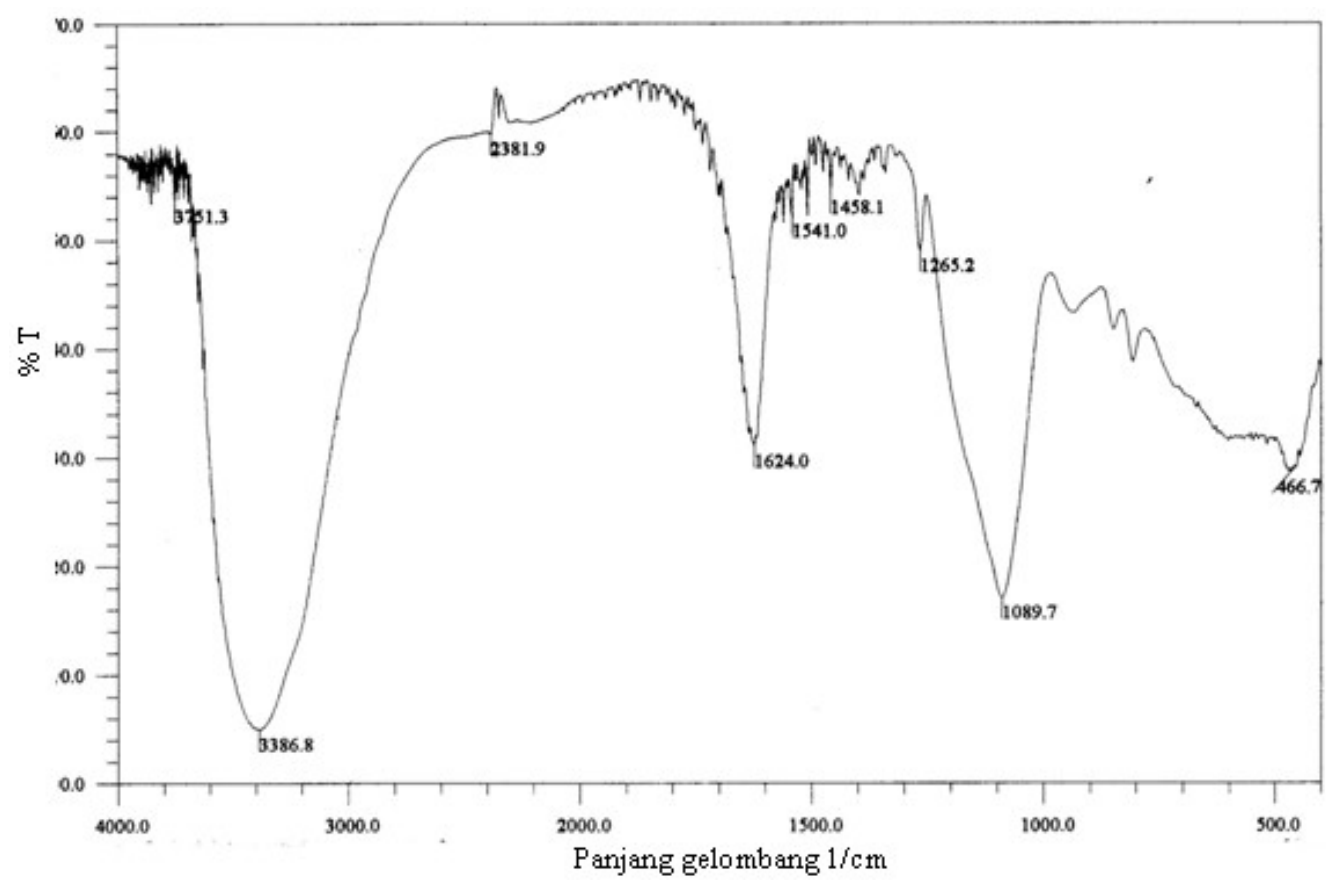

Gambar 5. Spektra zirkonium tetraklorid hasil proses, dianalisis dengan FTIR

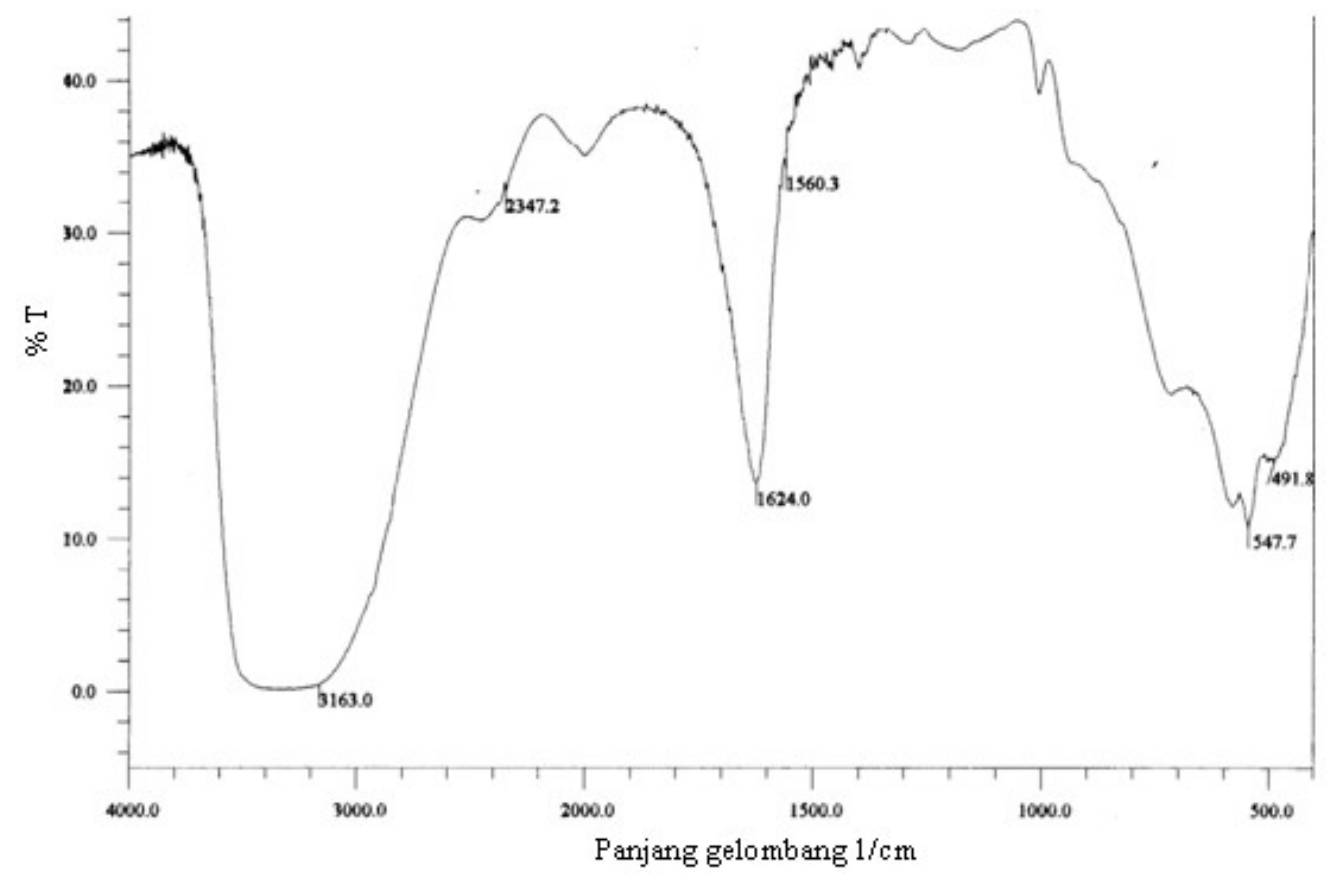

Gambar 6. Spektra zirkonium tetraklorid buatan Aldrich, dianalisis dengan FTIR 


\section{PEMBAHASAN}

Review ini menampilkan sejumlah penelitian klorinasi zirkon dioksida yang telah dilakukan. Dari paparan hasil penelitian yang telah dilakukan, secara garis besar dapat dilihat bahwa penelitian klorinasi pada awalnya dilakukan dengan menggunakan umpan zirkonium dioksida buatan Aldrich, dalam bentuk pelet. Pada tahap selanjutnya baru dilakukan klorinasi menggunakan pasir zirkon baik dalam bentuk briket ${ }^{(6-12)}$ maupun langsung dalam bentuk pasir zirkon ${ }^{(13,14,15,16,17,18)}$

Penelitian menggunakan zirkon dioksida buatan Aldrich sebagai umpan ${ }^{(2,3,4)}$ maupun pasir secara langsung atau dalam bentuk briket memberikan konversi yang kecil di bawah 30\%. Faktor alat sangat berpengaruh, karena pengambilan hasil sesudah proses selesai dan peralatan dingin, menunjukkan adanya sublimat putih pada bagian atas reaktor, pada pipa penghubung antara reaktor dan sublimator, hasil analisis menunjukkan adanya zirkon dalam sublimat tersebut. Hal ini membuktikan alat yang digunakan kurang sempurna, sehingga desublimasi yang seharusnya hanya terjadi dalam sublimator, dapat terjadi di tempat lain. Dari peralatan sublimator yang digunakan efisiensi sublimator kecil. Pembuatan alat yang memenuhi skala laboratorium keteknikan banyak menemui kendala, karena terbentur biaya dan peralatan yang diperlukan. Sebagian konstante yang diperlukan untuk perancangan alat seperti konstante kecepatan reaksi, koefisien perpindahan massa, orde reaksi, mekanisme reaksi, yang mendukung perancangan alat sudah diperoleh dalam penelitian. Secara teoritis penggunaan reaktor datar akan memberikan konversi yang kecil, karena gas $\mathrm{Cl}_{2}$ yang digunakan dalam proses klorinasi hanya akan bereaksi dengan briket yang ada di permukaan reaktor saja, karena gas $\mathrm{Cl}_{2}$ tidak dapat menembus sampai ke dalam. Selain itu sisa hasil reaksi berupa padatan yang tidak bereaksi akan menutup permukaan briket yang belum bereaksi, sehingga menghalangi reaksi lebih lanjut, karena reaksi berlangsung secara shrinking core model ${ }^{(3)}$. Penggunaan reaktor tegak memberikan harapan lebih besar baik menggunakan umpan zirkon dioksida buatan Aldrich maupun pasir zirkon. Bila kapasitas alat diperbesar, kemungkinan konversi yang diperoleh lebih besar, karena pembuatan alat sesuai standar keteknikan lebih mudah, hanya biayanya lebih besar. Secara keseluruhan diperlukan modifikasi peralatan, agar didapatkan konversi yang lebih besar, tetapi $\mathrm{ZrCl}_{4}$ hasil proses sudah signifikan dengan $\mathrm{ZrCl}_{4}$ buatan Aldrich.

\section{KESIMPULAN}

Dari review yang telah dipaparkan dapat ditarik kesimpulan sebagai berikut

1. Penelitian klorinasi menggunakan reaktor tegak memberikan nilai konversi yang lebih tinggi dibandingkan dengan reaktor datar maupun proses fluidisasi.

2. Penelitian klorinasi yang telah dikerjakan memerlukan modifikasi reaktor klorinasi sehingga proses desublimasi hanya terjadi dalam sublimator.

3. Sublimator juga perlu modifikasi sehingga efisiensinya bisa bertambah besar.

4. Diperlukan penelitian lebih lanjut untuk mendapatkan hasil proses yang lebih baik. Penelitian lanjutan akan lebih melengkapi teknologi yang diperlukan untuk lebih memajukan industri di Indonesia

\section{DAFTAR PUSTAKA}

1. LUSTMAN,B AND KERZE,F, "The Metallurgy of Zirconium", edisi1, p1-215, Mc Graw Hill Book Company Inc., New York (1955)

2. MIN CHEN,Y,WEN CHANG,F. and YUAN CHANG,C.,"Chlorination of Silicon Dioxide in the Presence of Carbon", Ind. Eng. Chem. Res.,29(1990).

3. DWIRETNANI SUDJOKO,BUSRON MASDUKI," Kinetika Klorinasi Zirkon Dioksida", Prosiding Pertemuan dan Presentasi IImiah, P3TM -BATAN, Yogyakarta (1994)

4. DWIRETNANI SUDJOKO, "Mekanisme Klorinasi Zirkon Dioksida" Jurnal Nusantara Kimia JNK94.1.2(1994).

5. BUSRON,M,PRAMUDITA ANGGRAITA, DWIRETNANI," Pemurnian dan Pembuatan Logam Zirkonium Hasil dan Prospeknya di Indonesia" Prosiding Kongres Ilmu Pengetahuan Nasional VI, Jakarta (1995). 
6. SUNARDJO,BUDI SULISTYO,DWIRETNANI SUDJOKO, "Pengaruh Ukuran Briket dan Kecepatan Alir Gas Klor Pada Klorinasi $\mathrm{ZrO}_{2}$ Hasil Olahan Pasir Zirkon "Prosiding Pertemuan dan Presentasi IImiah, P3TM-BATAN, Yogyakarta (1999).

7. SUNARDJO, DWIRETNANI SUDJOKO, BUDI SULISTYO, "Klorinasi Pasir Dalam Bentuk Briket," Prosiding Pertemuan dan Presentasi llmiah, P3TM-BATAN, Yogyakarta (2000).

8. SUNARDJO, DWIRETNANI SUDJOKO, BUDI SULISTYO, "Pengaruh Jumlah Oksigen dan Ukuran Butir Karbon Pada Klorinasi Pasir Zirkon Dalam Bentuk Briket Dengan Reaktor Datar," Prosiding Pertemuan dan Presentasi IImiah, P3TM-BATAN, Yogyakarta (2001).

9. SUNARDJO, DWIRETNANI SUDJOKO, BUDI SULISTYO, PRISTI HARTATI, "Pengaruh Distributor Gas Klor dan Ukuran Briket Pada Klorinasi Pasir Zirkon", Prosiding Pertemuan dan Presentasi IImiah, P3TMBATAN, Yogyakarta (2002).

10. BUDI SULISTYO, SUNARDJO, DWIRETNANI SUDJOKO, PRISTI HARTATI, "Pengaruh Kecepatan Alir Gas $\mathrm{Cl}_{2}$ dan Tinggi Bed Terhadap Hasil $\mathrm{ZrCl}_{4}$ Pada Proses Klorinasi Pasir Zirkon”, Prosiding Pertemuan dan Presentasi IImiah, P3TM-BATAN, Yogyakarta (2001).

11. BUDI SULISTYO, SUNARDJO, DWIRETNANI SUDJOKO, PRISTI HARTATI, "Pengaruh Komposisi dan Tekanan Pada Pembuatan Briket Pasir Zirkon Terhadap Konversi Klorinasi," Prosiding Pertemuan dan Presentasi IImiah, P3TM-BATAN, Yogyakarta (2002).

12. BUDI SULISTYO, SUNARDJO, DWIRETNANI SUDJOKO, PRISTI HARTATI, "Pengaruh Jenis Karbon Pada Pembuatan Briket Pasir Zirkon Terhadap Konversi Klorinasi," Prosiding Pertemuan dan Presentasi IImiah, P3TM-BATAN, Yogyakarta (2003).

13.DWIRETNANI SUDJOKO, BUDI SULISTYO, SUNARDJO, "Pengaruh Waktu, Perbandingan Pereaksi,Ukuran Butir Pasir Pada Klorinasi Pasir Zirkon Menggu- nakan Fixed Bed Reaktor,"Prosiding Pertemuan dan Presentasi Ilmiah, P3TM- BATAN, Yogyakarta (2001).

14.DWIRETNANI SUDJOKO, BUDI SULISTYO, PRISTI HARTATI ,SUNARDJO, "Klorinasi Pasir Zirkon Secara Langsung", Prosiding Pertemuan dan Presentasi Ilmiah, P3TM-BATAN, Yogyakarta (2002).


dan Fe", Prosiding Pertemuan dan Presentasi IImiah, P3TM-BATAN, Yogyakarta (2003).

16.SUNARDJO, DWIRETNANI, BUDI SULISTYO, PRISTI H, "Proses Fluidisasi pada Klorinasi Pasir Zirkon", Prosiding Pertemuan dan Presentasi IImiah, P3TM- BATAN, Yogyakarta (2003).

17. SUNARDJO,DWIRETNANI,BUDI SULISTYO, PRISTI H," Pengaruh Kecepatan Fluidisasi dan Kecepatan Gas Khlor Pada Klorinasi Pasir Zirkon", Prosiding Pertemuan dan Presentasi IImiah, P3TM-BATAN, Yogyakarta (2004).

18. SUNARDJO,DWIRETNANI,BUDI SULISTYO, PRISTI H," Pengaruh Ukuran Butir Pasir dan Jumlah Kokas Pada Klorinasi Pasir Zirkon", Prosiding Pertemuan dan Presentasi IImiah, P3TM-BATAN, Yogyakarta (2005).

19. DWIRETNANI SUDJOKO, BUSRON MASDUKI, SUNARDJO, BUDI SULIS- TYO,"Koefisien Perpindahan Massa Pada Desublimasi Zirkon Tetraklorid", JNK.96.1.2(1996).

20.DWIRETNANI SUDJOKO, Elin Nuraini, Sajima, "Pemurnian $\mathrm{ZrCl}_{4}$ dengan Distilasi Fraksinasi ",Prosiding Seminar Jasa KIAl, Yogyakarta (2003).

21.DWIRETNANI SUDJOKO, "Efisiensi Sublimator Pada Klorinasi Pasir Zirkon" Prosiding Pertemuan dan Presentasi IImiah, P3TM-BATAN, Yogyakarta (2003).

22. CONLEY,R.T, Infrared Spectroscopy, 201-211, 259-275,Allyn and Bacon, Inc., Boston (1975). 